\title{
Relationship Between Postoperative CRP and Prognosis in Thoracic Esophageal Squamous Cell Carcinoma
}

\author{
KEITA KATSURAHARA, ATSUSHI SHIOZAKI, HITOSHI FUJIWARA, HIROTAKA KONISHI, \\ MICHIHIRO KUDOU, KATSUTOSHI SHODA, TOMOHIRO ARITA, TOSHIYUKI KOSUGA, \\ RYO MORIMURA, YASUTOSHI MURAYAMA, YOSHIAKI KURIU, HISASHI IKOMA, \\ TAKESHI KUBOTA, MASAYOSHI NAKANISHI, KAZUMA OKAMOTO and EIGO OTSUJI
}

Division of Digestive Surgery, Department of Surgery, Kyoto Prefectural University of Medicine, Kyoto, Japan

\begin{abstract}
Background/Aim: Few studies have examined postoperative CRP in esophageal cancer. We investigated the relationship between postoperative CRP values according to the postoperative period and prognosis in esophageal cancer. Patients and Methods: We performed a retrospective cohort study including 187 patients who underwent esophagectomy for esophageal squamous cell carcinoma (ESCC) between January 2008 and October 2016. Results: CRP within 1 month of surgery was not related to overall survival (OS) or recurrence-free survival (RFS). In a univariate analysis, postoperative 2 months (2M)-CRP $\geq 0.15 \mathrm{ml} / \mathrm{dl}$ was associated with poorer OS (41.4 vs. 71.4\%, $p=0.0002)$ and RFS (28.9 vs. 51.3\%, $p=0.007)$. In a multivariate analysis, $2 M-C R P \geq 0.15 \mathrm{ml} / \mathrm{dl}$ was an independent factor for poorer OS $(H R=2.27,95 \% C I=1.03-3.34, p=0.005)$ and $R F S$ $(H R=1.65,95 \% C I=1.08-2.52, p=0.020)$. The incidence of postoperative pneumonia was significantly higher in the $2 M$ $C R P \geq 0.15 \mathrm{ml} / \mathrm{dl}$ group $(p=0.026)$. Conclusion: $2 M-C R P$ $\geq 0.15 \mathrm{ml} / \mathrm{dl}$ is an independent prognostic factor for ESCC. Furthermore, postoperative pneumonia may be associated with patient prognosis after esophagectomy.
\end{abstract}

Esophageal cancer is the eighth most common cancer worldwide, and the sixth most common cause of death from cancer (1). Multimodal therapy and perioperative management have recently improved; however, the prognosis of patients with esophageal cancer remains poor (2). A relationship has been reported between inflammation and malignant tumors. C-reactive protein (CRP) is the most common biomarker of

Correspondence to: Dr. Atsushi Shiozaki, Assistant Professor, Division of Digestive Surgery, Department of Surgery, Kyoto Prefectural University of Medicine, 465 Kajii-cho, Kamigyo-ku, Kyoto 602-8566, Japan. Tel: +81 752515527, Fax: +81 752515522, e-mail: shiozaki@koto.kpu-m.ac.jp

Key Words: Postoperative CRP, esophageal cancer. inflammation. Previous studies demonstrated that preoperative serum CRP was a prognostic factor for various types of cancers, such as colorectal cancer (3), esophageal cancer (4), and urological cancer (5). Some studies also examined postoperative CRP within 1 month of surgery for esophageal cancer $(6,7)$ and other cancers $(8,9)$. However, there is currently no information on CRP levels 2 months after surgery.

Postoperative complications may induce postoperative inflammation. The relationship between postoperative complications and patient prognosis has been investigated for various types of cancers $(10,11)$. However, the relationship between postoperative complications and patient prognosis in esophageal cancer remains controversial. In the present study, we investigated the relationships between postoperative CRP up to 2 months postoperatively, postoperative complications, and patient prognosis in ESCC.

\section{Patients and Methods}

Patients. We performed a retrospective cohort study including 187 patients who underwent esophagectomy for thoracic ESCC between January 2008 and October 2016 at our institution, for whom CRP values from the perioperative period to 2 months after surgery were noted. We excluded patients who received radiation therapy before surgery and patients with non-curative resected tumors. We selected a postoperative observation period of up to 5 years.

We evaluated superficial incisional surgical site infections (SSSI), pneumonia, anastomotic leakage, and recurrent nerve paralysis as postoperative complications. All histopathological diagnoses were performed by experienced pathologists. T, N, and $\mathrm{M}$ categories and pathological stages were classified according to the pTNM Pathological Classification (UICC International Union Against Cancer TNM Classification of Malignant Tumors; 8th edition) (12).

CRP value measurements. Serum CRP levels were measured on postoperative days (PODs) $1,3,5,7$, and 14 and postoperative 1 month (1M) and 2 months (2M). According to our institution's standard, we set the cut-off value for $1 \mathrm{M}-\mathrm{CRP}$ and $2 \mathrm{M}-\mathrm{CRP}$ at $0.15 \mathrm{mg} / \mathrm{dl}$. Since CRP elevations in most patients were confirmed within 14 days of surgery, we defined Max-CRP as the maximum CRP value on PODs $1,3,5,7$, and 14 . The cut-off value for Max-CRP was set as $20 \mathrm{mg} / \mathrm{dl}$. 
Table I. Patient characteristics and CRP after surgery.

\begin{tabular}{|c|c|c|c|c|c|c|c|c|c|c|}
\hline \multirow[t]{2}{*}{ Variable } & \multirow[b]{2}{*}{$\mathrm{n}$} & \multicolumn{2}{|c|}{ Max-CRP } & \multirow[t]{2}{*}{$p$-Value } & \multicolumn{2}{|c|}{ 1M-CRP } & \multirow[t]{2}{*}{$p$-Value } & \multicolumn{2}{|c|}{ 2M-CRP } & \multirow[t]{2}{*}{$p$-Value } \\
\hline & & $\begin{array}{c}<20 \\
(\mathrm{n}=120)\end{array}$ & $\begin{array}{c}\geq 20 \\
(\mathrm{n}=67)\end{array}$ & & $\begin{array}{l}<0.15 \\
(\mathrm{n}=47)\end{array}$ & $\begin{array}{c}\geq 0.15 \\
(\mathrm{n}=140)\end{array}$ & & $\begin{array}{c}<0.15 \\
(\mathrm{n}=101)\end{array}$ & $\begin{array}{l}\geq 0.15 \\
(\mathrm{n}=86)\end{array}$ & \\
\hline \multicolumn{11}{|l|}{ Age } \\
\hline$<70$ & 114 & 74 & 40 & \multirow[t]{2}{*}{0.876} & 33 & 81 & \multirow[t]{2}{*}{0.167} & 77 & 37 & \multirow[t]{2}{*}{$<0.0001^{*}$} \\
\hline$\geq 70$ & 73 & 46 & 27 & & 14 & 59 & & 24 & 49 & \\
\hline \multicolumn{11}{|l|}{ Gender } \\
\hline Male & 151 & 92 & 59 & \multirow[t]{2}{*}{0.081} & 35 & 116 & \multirow[t]{2}{*}{0.208} & 73 & 78 & \multirow[t]{2}{*}{$0.002^{*}$} \\
\hline Female & 36 & 28 & 8 & & 12 & 24 & & 28 & 8 & \\
\hline \multicolumn{11}{|c|}{ BMI $\left(\mathrm{kg} / \mathrm{m}^{2}\right)$} \\
\hline$<22$ & 112 & 85 & 27 & \multirow[t]{2}{*}{$<0.0001^{*}$} & 31 & 81 & \multirow[t]{2}{*}{0.391} & 60 & 52 & \multirow[t]{2}{*}{1.000} \\
\hline$\geq 22$ & 75 & 35 & 40 & & 16 & 59 & & 41 & 34 & \\
\hline \multicolumn{11}{|c|}{$\mathrm{HbA1c}(\%)$} \\
\hline$<6.2$ & 157 & 104 & 53 & \multirow[t]{2}{*}{0.215} & 39 & 118 & \multirow[t]{2}{*}{0.819} & 86 & 71 & \multirow[t]{2}{*}{0.690} \\
\hline$\geq 6.2$ & 30 & 16 & 14 & & 8 & 22 & & 15 & 15 & \\
\hline \multicolumn{11}{|c|}{ Tumor location } \\
\hline $\mathrm{Ut}$ & 29 & 15 & 14 & \multirow[t]{2}{*}{0.144} & 4 & 25 & \multirow[t]{2}{*}{0.164} & 13 & 16 & \multirow[t]{2}{*}{0.315} \\
\hline $\mathrm{Mt} / \mathrm{Lt}$ & 158 & 105 & 53 & & 43 & 115 & & 88 & 70 & \\
\hline \multicolumn{11}{|c|}{ Surgical time (min) } \\
\hline$<360$ & 77 & 60 & 17 & $0.001 *$ & 25 & 52 & 0.061 & 35 & 42 & 0.054 \\
\hline$\geq 360$ & 110 & 60 & 50 & & 22 & 88 & & 66 & 44 & \\
\hline Blood los & & & & & & & & & & \\
\hline$<300$ & 97 & 76 & 21 & $<0.0001^{*}$ & 32 & 65 & $0.012^{*}$ & 53 & 44 & 0.884 \\
\hline$\geq 300$ & 90 & 44 & 46 & & 15 & 75 & & 48 & 42 & \\
\hline pT & & & & & & & & & & \\
\hline pT1 & 75 & 42 & 33 & 0.063 & 17 & 58 & 0.607 & 42 & 33 & 0.765 \\
\hline pT2-3 & 112 & 78 & 34 & & 30 & 82 & & 59 & 53 & \\
\hline $\mathrm{pN}$ & & & & & & & & & & \\
\hline pNO & 78 & 47 & 31 & 0.358 & 19 & 59 & 0.866 & 47 & 31 & 0.181 \\
\hline $\mathrm{pN} 1-3$ & 109 & 73 & 36 & & 28 & 81 & & 54 & 55 & \\
\hline
\end{tabular}

BMI: Body mass index; Ut: upper esophagus; Mt: middle thoracic esophagus; Lt: lower esophagus; pT: pathological T stage; pN: pathological N stage. ${ }^{*} p<0.05$ : Fisher's exact test.

Statistical analysis. Data in our computerized database were examined in this retrospective study. Additional data were obtained by reviewing medical records. All analyses were performed using JMP software (version 12, SAS Institute Inc., Cary, NC, USA). Data were compared using Fisher's exact test to evaluate differences between qualitative variables. Survival curves were generated by the Kaplan-Meier method, and comparisons between groups were analyzed using the Log-rank test. A multivariate analysis was performed using Cox's proportional hazards model. A $p$-value of less than 0.05 was considered to be significant.

\section{Results}

Patient characteristics and CRP after surgery. We showed the characteristics of 187 patients, and compared clinical parameters between the high and low CRP groups in each period (Table I). Sixty-seven out of 187 (35.8\%) patients were classified into the Max-CRP $\geq 20 \mathrm{mg} / \mathrm{dl}$ group, 140 (74.9\%) into the $1 \mathrm{M}-\mathrm{CRP} \geq 0.15 \mathrm{mg} / \mathrm{dl}$ group, and 86 (46.0\%) into the $2 \mathrm{M}$-CRP $\geq 0.15 \mathrm{mg} / \mathrm{dl}$. No significant differences were observed in age, HbA1c, tumor location, or $\mathrm{pN}$ in each period between the high and low CRP groups. The Max-CRP $\geq 20 \mathrm{mg} / \mathrm{dl}$ group had a significantly higher proportion of $\mathrm{BMI} \geq 22$, surgical time $\geq 360 \mathrm{~min}$, and blood loss $\geq 300 \mathrm{ml}$. Furthermore, there were significantly more patients with $1 \mathrm{M}$-CRP $\geq 0.15 \mathrm{mg} / \mathrm{dl}$ in the blood loss $\geq 300 \mathrm{ml}$ group, and also significantly more patients with $2 \mathrm{M}-\mathrm{CRP} \geq 0.15 \mathrm{mg} / \mathrm{dl}$ in the age $\geq 70$ years group.

Prognosis after surgery. We compared OS and RFS with each clinicopathological factor (Tables II and III). 2M-CRP $\geq 0.15 \mathrm{ml} / \mathrm{dl}$ was associated with poorer OS (41.4 vs. $71.4 \%$, $p=0.0002)$ and RFS (28.9 vs. $51.3 \%, p=0.007)$. In the multivariate analysis, $2 \mathrm{M}-\mathrm{CRP} \geq 0.15 \mathrm{ml} / \mathrm{dl}$ was an independent factor for poorer OS $(\mathrm{HR}=2.27,95 \% \mathrm{CI}=1.03$ $3.34, p=0.005)$ and RFS $(\mathrm{HR}=1.65,95 \% \mathrm{CI}=1.08-2.52$, $p=0.020$ ). We made survival curves using the Kaplan-Meier method (Figure 1), which showed that the 2M-CRP $\geq 0.15 \mathrm{mg} / \mathrm{dl}$ group had poor OS and RFS in each period. 
Table II. Overall survival rates.

\begin{tabular}{|c|c|c|c|c|c|c|}
\hline \multirow[t]{2}{*}{ Variable } & \multirow{2}{*}{$\begin{array}{c}\text { Total } \\
\mathrm{n}\end{array}$} & \multirow[t]{2}{*}{ OS $(\%)$} & \multirow{2}{*}{$\begin{array}{c}\text { Univariate analysis } \\
p \text {-Value }\end{array}$} & \multicolumn{3}{|c|}{ Multivariate analysis } \\
\hline & & & & HR & $95 \% \mathrm{CI}$ & $p$-Value \\
\hline \multicolumn{7}{|l|}{ Age } \\
\hline$<70$ & 114 & $66.4 \%$ & $0.024 *$ & 1.33 & $0.75-2.35$ & 0.328 \\
\hline$\geq 70$ & 73 & $45.3 \%$ & & & & \\
\hline \multicolumn{7}{|l|}{ Gender } \\
\hline Male & 151 & $58.0 \%$ & 1.000 & & & \\
\hline Female & 36 & $62.0 \%$ & & & & \\
\hline \multicolumn{7}{|l|}{ BMI } \\
\hline$<22$ & 112 & $57.5 \%$ & 0.844 & & & \\
\hline$\geq 22$ & 75 & $62.2 \%$ & & & & \\
\hline \multicolumn{7}{|c|}{ HbA1c (\%) } \\
\hline$<6.2$ & 157 & $61.9 \%$ & 0.204 & & & \\
\hline$\geq 6.2$ & 30 & $42.1 \%$ & & & & \\
\hline \multicolumn{7}{|c|}{ Tumor location } \\
\hline Ut & 29 & $79.9 \%$ & 0.065 & & & \\
\hline $\mathrm{Mt} / \mathrm{Lt}$ & 158 & $55.8 \%$ & & & & \\
\hline \multicolumn{7}{|c|}{ Surgical time $(\min )$} \\
\hline$<360$ & 77 & $56.9 \%$ & 0.424 & & & \\
\hline$\geq 360$ & 110 & $60.5 \%$ & & & & \\
\hline \multicolumn{7}{|c|}{ Blood loss (ml) } \\
\hline$<300$ & 97 & $61.8 \%$ & 0.888 & & & \\
\hline$\geq 300$ & 90 & $57.0 \%$ & & & & \\
\hline \multicolumn{7}{|l|}{ pT } \\
\hline pT1 & 75 & $67.9 \%$ & $0.022 *$ & 1.81 & $1.04-3.33$ & $0.037 * *$ \\
\hline pT2-3 & 112 & $53.5 \%$ & & & & \\
\hline \multicolumn{7}{|l|}{$\mathrm{pN}$} \\
\hline pNO & 78 & $71.4 \%$ & $0.018^{*}$ & 1.81 & $1.03-3.34$ & $0.040 * *$ \\
\hline $\mathrm{pN} 1-3$ & 109 & $51.0 \%$ & & & & \\
\hline \multicolumn{7}{|c|}{ Preoperative CRP (mg/dl) } \\
\hline$<0.15$ & 121 & $58.6 \%$ & 0.936 & & & \\
\hline$\geq 0.15$ & 66 & $60.5 \%$ & & & & \\
\hline \multicolumn{7}{|c|}{ Max-CRP (mg/dl) } \\
\hline$<20$ & 120 & $57.5 \%$ & 0.529 & & & \\
\hline$\geq 20$ & 67 & $61.4 \%$ & & & & \\
\hline \multicolumn{7}{|c|}{$1 \mathrm{M}-\mathrm{CRP}(\mathrm{mg} / \mathrm{dl})$} \\
\hline$<0.15$ & 47 & $68.6 \%$ & 0.173 & & & \\
\hline$\geq 0.15$ & 140 & $55.5 \%$ & & & & \\
\hline \multicolumn{7}{|c|}{$2 \mathrm{M}-\mathrm{CRP}(\mathrm{mg} / \mathrm{dl})$} \\
\hline$<0.15$ & 101 & $71.4 \%$ & $0.0002 *$ & 2.27 & $1.03-3.34$ & $0.005 * *$ \\
\hline$\geq 0.15$ & 86 & $41.4 \%$ & & & & \\
\hline
\end{tabular}

BMI: Body mass index; Ut: upper esophagus; Mt: middle thoracic esophagus; Lt: lower esophagus; pT: pathological T stage; pN: pathological N stage. ${ }^{*} p<0.05$ : Log-rank test; ${ }^{* *} p<0.05$ : Cox's hazard regression analysis.

CRP after surgery and postoperative complications. Postoperative complications between the 2M-CRP $<0.15$ $\mathrm{mg} / \mathrm{dl}$ group and $\geq 0.15 \mathrm{mg} / \mathrm{dl}$ group were compared (Table IV). No significant differences were observed in S-SSI, anastomotic leakage, or recurrent nerve paralysis between the two groups. However, the incidence of pneumonia was significantly higher in the $2 \mathrm{M}-\mathrm{CRP} \geq 0.15 \mathrm{mg} / \mathrm{dl}$ group.

\section{Discussion}

CRP is a blood test marker for inflammation in the body, and is produced in the liver. CRP is classified as an acute phase reactant and increases in response to inflammation. CRP plays a key role in host defenses against infection and was given its name because it reacts with the C-polysaccharide of Streptococcus pneumoniae (13). This is the first study to investigate the relationship between CRP 2 months after surgery and patient prognosis. In the present study, 2M-CRP $\geq 0.15 \mathrm{mg} / \mathrm{dl}$ was associated with significantly poorer OS and RFS. Ibuki et al. previously reported that 7PODs-CRP and 1M-CRP were associated with poor RFS (6). Matsuda et al. showed that an intense postoperative inflammatory response (CRP within 14 days of surgery) was an independent risk factor for poor OS and RFS (7). In this study, CRP within 1 month 
Table III. Recurrence-free survival rates.

\begin{tabular}{|c|c|c|c|c|c|c|}
\hline & \multirow{2}{*}{$\begin{array}{c}\text { Total } \\
\mathrm{n}\end{array}$} & \multirow[t]{2}{*}{ RFS (\%) } & \multirow{2}{*}{$\begin{array}{c}\text { Univariate analysis } \\
p \text {-Value }\end{array}$} & \multicolumn{3}{|c|}{ Multivariate analysis } \\
\hline & & & & $\mathrm{HR}$ & $95 \% \mathrm{CI}$ & $p$-Value \\
\hline \multicolumn{7}{|l|}{ Age } \\
\hline$<70$ & 114 & $46.7 \%$ & 0.304 & & & \\
\hline$\geq 70$ & 73 & $30.8 \%$ & & & & \\
\hline \multicolumn{7}{|l|}{ Gender } \\
\hline Male & 151 & $41.4 \%$ & 0.958 & & & \\
\hline Female & 36 & $42.9 \%$ & & & & \\
\hline \multicolumn{7}{|l|}{ BMI } \\
\hline$<22$ & 112 & $37.8 \%$ & 0.483 & & & \\
\hline$\geq 22$ & 75 & $51.4 \%$ & & & & \\
\hline \multicolumn{7}{|c|}{$\mathrm{HbA} 1 \mathrm{c}(\%)$} \\
\hline$<6.2$ & 157 & $40.4 \%$ & 0.661 & & & \\
\hline$\geq 6.2$ & 30 & $51.6 \%$ & & & & \\
\hline \multicolumn{7}{|c|}{ Tumor location } \\
\hline Ut & 29 & $58.7 \%$ & 0.141 & & & \\
\hline $\mathrm{Mt} / \mathrm{Lt}$ & 158 & $39.1 \%$ & & & & \\
\hline \multicolumn{7}{|c|}{ Surgical time (min) } \\
\hline$<360$ & 77 & $34.8 \%$ & 0.110 & & & \\
\hline$\geq 360$ & 110 & $46.8 \%$ & & & & \\
\hline \multicolumn{7}{|c|}{ Blood loss (ml) } \\
\hline$<300$ & 97 & $33.4 \%$ & 0.230 & & & \\
\hline$\geq 300$ & 90 & $48.8 \%$ & & & & \\
\hline \multicolumn{7}{|l|}{ pT } \\
\hline pT1 & 75 & $65.7 \%$ & $<0.0001 *$ & 2.87 & $1.77-4.85$ & $<0.0001 * *$ \\
\hline pT2-3 & 112 & $27.6 \%$ & & & & \\
\hline \multicolumn{7}{|l|}{$\mathrm{pN}$} \\
\hline pNO & 78 & $52.5 \%$ & $0.0009^{*}$ & 1.89 & $1.21-3.05$ & $0.005^{* *}$ \\
\hline pN1-3 & 109 & $34.3 \%$ & & & & \\
\hline \multicolumn{7}{|c|}{ Preoperative CRP (mg/dl) } \\
\hline$<0.15$ & 121 & $45.2 \%$ & 0.772 & & & \\
\hline$\geq 0.15$ & 66 & $37.3 \%$ & & & & \\
\hline \multicolumn{7}{|c|}{ Max-CRP (mg/dl) } \\
\hline$<20$ & 120 & $40.0 \%$ & 0.294 & & & \\
\hline$\geq 20$ & 67 & $45.5 \%$ & & & & \\
\hline \multicolumn{7}{|c|}{$1 \mathrm{M}-\mathrm{CRP}(\mathrm{mg} / \mathrm{dl})$} \\
\hline$<0.15$ & 47 & $53.1 \%$ & 0.262 & & & \\
\hline$\geq 0.15$ & 140 & $37.3 \%$ & & & & \\
\hline \multicolumn{7}{|c|}{$2 \mathrm{M}-\mathrm{CRP}(\mathrm{mg} / \mathrm{dl})$} \\
\hline$<0.15$ & 101 & $51.3 \%$ & $0.007 *$ & 1.65 & $1.08-2.52$ & 0.020 ** \\
\hline$\geq 0.15$ & 86 & $28.9 \%$ & & & & \\
\hline
\end{tabular}

BMI: Body mass index; Ut: upper esophagus; Mt: middle thoracic esophagus; Lt: lower esophagus; pT: pathological T stage; pN: pathological N stage. ${ }^{*} p<0.05$ : Log-rank test; ${ }^{* *} p<0.05$ : Cox's hazard regression analysis.

was not associated with patient prognosis. On the other hand, $2 \mathrm{M}-\mathrm{CRP} \geq 0.15 \mathrm{mg} / \mathrm{dl}$ was associated with significantly poorer OS and RFS. These results indicate that chronic rather than acute inflammation is associated with enhanced cancer growth. Although it is widely known that chronic inflammation is involved in carcinogenesis, for example, hepatic cell carcinoma, gastric cancer, and cervical cancer (14), few studies have investigated its relationship with cancer growth. Petrzyk et al. reported that obesity-related chronic inflammation induced cancer cell proliferation, invasion, and metastasis via the activation of several signal transduction pathways (JAK/STAT, mitogen-activated protein kinase (MAPK), phosphatidylinositol 3 kinase (PI3K), and mTOR) in colorectal cancer (15).

In the present study, the incidence of pneumonia was significantly higher in the $2 \mathrm{M}-\mathrm{CRP} \geq 0.15 \mathrm{mg} / \mathrm{dl}$ group. On the other hand, Max-CRP $\geq 20 \mathrm{mg} / \mathrm{dl}$ and $1 \mathrm{M}-\mathrm{CRP} \geq 0.15 \mathrm{mg} / \mathrm{dl}$ were not associated with the occurrence of pneumonia. This has been attributed to postoperative pneumonia after esophagectomy occurring at various times after surgery. Previous studies also reported that postoperative pneumonia was associated with a poor prognosis in patients with esophageal cancer $(16,17)$. These findings suggest the 

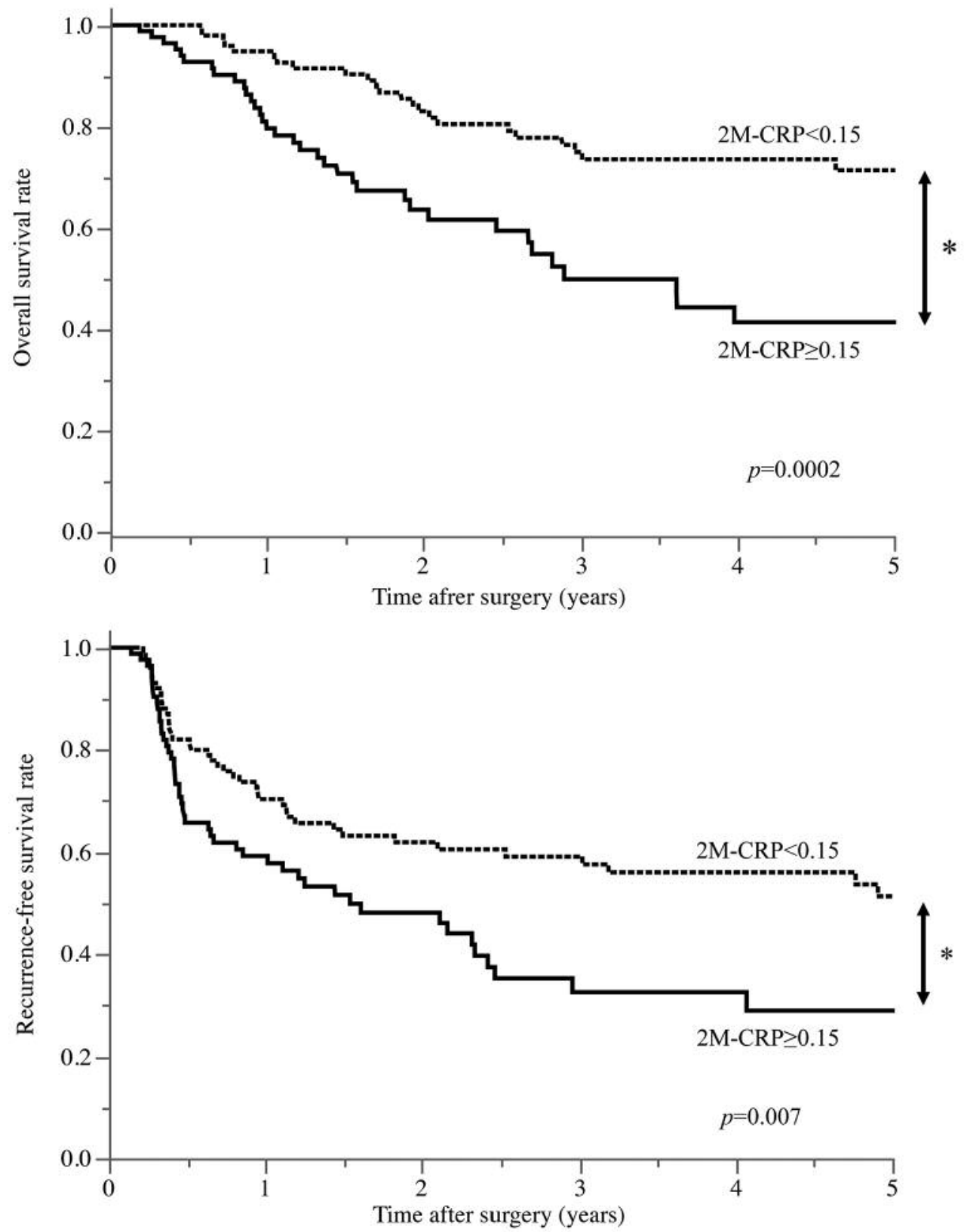

Figure 1. Survival curves of patients after curative resection for ESCC according to postoperative CRP levels. OS (upper panel) and RFS (lower panel) were poor in the $2 M$-CRP $\geq 0.15 \mathrm{mg} / \mathrm{dl}$ group in each period. ${ }^{*} p<0.05$ : Log-rank test.

importance of minimally invasive esophagectomy, which may decrease the incidence of postoperative respiratory complications, from an oncological point of view (18-20).

There is also evidence to indicate that tumor growth increases CRP (21); however, it currently remains unclear whether elevated CRP is the cause or result of cancer growth. In the present study on patients with curative resected tumors, there were no relationships between postoperative CRP values and oncological factors, such as $\mathrm{pT}$ and $\mathrm{pN}$, suggesting that our results on CRP were mainly influenced by inflammatory rather than oncological factors. In conclusion, 2M-CRP $\geq 0.15 \mathrm{ml} / \mathrm{dl}$ was identified as an independent prognostic factor for ESCC. Furthermore, postoperative pneumonia may be associated with patient prognosis after esophagectomy.

\section{Conflicts of Interest}

The Authors declare that they have no conflict of interest. 
Table IV. CRP after surgery and postoperative complications.

\begin{tabular}{|c|c|c|c|c|}
\hline \multirow[t]{2}{*}{ Complication } & \multirow{2}{*}{$\begin{array}{c}\text { Total } \\
\mathrm{n}\end{array}$} & \multicolumn{2}{|c|}{ 2M-CRP } & \multirow[t]{2}{*}{$* p$-Value } \\
\hline & & $<0.15(\mathrm{n}=101)$ & $\geq 0.15(n=86)$ & \\
\hline \multicolumn{5}{|l|}{ S-SSI } \\
\hline Present & 12 & 8 & 4 & 0.551 \\
\hline Absent & 175 & 93 & 82 & \\
\hline \multicolumn{5}{|l|}{ Pneumonia } \\
\hline Present & 29 & 10 & 19 & $0.026^{*}$ \\
\hline Absent & 158 & 91 & 67 & \\
\hline \multicolumn{5}{|c|}{ Anastomotic leakage } \\
\hline Present & 27 & 12 & 15 & 0.303 \\
\hline Absent & 160 & 89 & 71 & \\
\hline \multicolumn{5}{|c|}{ Recurrent nerve paralysis } \\
\hline Present & 76 & 39 & 37 & 0.554 \\
\hline Absent & 111 & 62 & 49 & \\
\hline
\end{tabular}

S-SSI: Superficial incisional surgical site infection. ${ }^{*} p<0.05$ : Fisher's exact test.

\section{References}

1 Ferlay J, Soerjomataram I, Dikshit R, Eser S, Mathers C, Rebelo M, Parkin DM, Forman D and Bray F: Cancer incidence and mortality worldwide: sources, methods and major patterns in GLOBOCAN 2012. Int J Cancer 136: E359-386, 2015.

2 Takeuchi H, Miyata H, Gotoh M, Kitagawa Y, Baba H, Kimura W, Tomita N, Nakagoe T, Shimada M, Sugihara K and Mori M: A risk model for esophagectomy using data of 5354 patients included in a Japanese nationwide web-based database. Ann Surg 260: 259-266, 2014.

3 Pathak S, Nunes QM, Daniels IR and Smart NJ: Is C-reactive protein useful in prognostication for colorectal cancer? A systematic review. Colorectal Dis 16: 769-776, 2014.

4 Zheng TL, Cao K, Liang C, Zhang K, Guo HZ, Li DP and Zhao $\mathrm{S}$ : Prognostic value of $\mathrm{C}$-reactive protein in esophageal cancer: a meta-analysis. Asian Pac J Cancer Prev 15: 8075-8081, 2014.

5 Saito $\mathrm{K}$ and Kihara K: C-reactive protein as a biomarker for urological cancers. Nat rev Urol 8: 659-666, 2011.

6 Ibuki Y, Hamai Y, Hihara J, Emi M, Taomoto J, Furukawa T, Yamakita I, Kurokawa T and Okada M: Role of postoperative C-reactive protein levels in predicting prognosis after surgical treatment of esophageal cancer. World J Surg 41: 1558-1565, 2017.

7 Matsuda S, Takeuchi H, Kawakubo H, Fukuda K, Nakamura R, Takahashi T, Wada N, Saikawa Y and Kitagawa Y: Correlation between intense postoperative inflammatory response and survival of esophageal cancer patients who underwent transthoracic esophagectomy. Ann Surg Oncol 22: 4453-4460, 2015.

8 Shinohara S, Sugaya M, Onitsuka T, Machida K, Matsuo M and Tanaka F: Prognostic impact of postoperative C-reactive protein for non-small cell lung cancer following lobectomy. Anticancer Res 38: 3193-3198, 2018.
9 Saito T, Kurokawa Y, Miyazaki Y, Makino T, Takahashi T, Yamasaki M, Nakajima K, Takiguchi S, Mori M and Doki Y: Which is a more reliable indicator of survival after gastric cancer surgery: Postoperative complication occurrence or C-reactive protein elevation? J Surg Oncol 112: 894-899, 2015.

10 Mrak K, Eberl T, Laske A, Jagoditsch M, Fritz J and Tschmelitsch J: Impact of postoperative complications on longterm survival after resection for rectal cancer. Dis Colon Rectum 56: 20-28, 2013.

11 Harimoto N, Shirabe K, Ikegami T, Yoshizumi T, Maeda T, Kajiyama K, Yamanaka $\mathrm{T}$ and Maehara Y: Postoperative complications are predictive of poor prognosis in hepatocellular carcinoma. J Surg Res 199: 470-477, 2015.

12 James DB, Mary KG and Christian W: International Union Against Cancer (UICC) TNM classification of malignant tumors, 8th edition. Wiley, New York, 2017.

13 Black S, Kushner I and Samols D: C-reactive protein. J Biol Chem 279: 48487-48490, 2004.

14 Aggarwal BB, Shishodia S, Sandur SK, Pandey MK and Sethi $\mathrm{G}$ : Inflammation and cancer: how hot is the link? Biochem Pharmacol 72: 1605-1621, 2006.

15 Pietrzyk L, Torres A, Maciejewski R and Torres K: Obesity and obese-related chronic low-grade inflammation in promotion of colorectal cancer development. Asian Pac J Cancer Prev 16: 4161-4168, 2015.

16 Kataoka K, Takeuchi H, Mizusawa J, Igaki H, Ozawa S, Abe T, Nakamura K, Kato K, Ando N and Kitagawa Y: Prognostic impact of postoperative morbidity after esophagectomy for esophageal cancer: exploratory analysis of JCOG9907. Ann Surg 265: 1152-1157, 2017.

17 Booka E, Takeuchi H, Nishi T, Matsuda S, Kaburagi T, Fukuda K, Nakamura R, Takahashi T, Wada N, Kawakubo H, Omori T and Kitagawa Y: The impact of postoperative complications on survivals after esophagectomy for esophageal cancer. Medicine (Baltimore) 94: e1369, 2015.

18 Fujiwara H, Shiozaki A, Konishi H, Kosuga T, Komatsu S, Ichikawa D, Okamoto $\mathrm{K}$ and Otsuji E: Perioperative outcomes of single-port mediastinoscope-assisted transhiatal esophagectomy for thoracic esophageal cancer. Dis Esophagus 30: 1-8, 2017.

19 Noshiro H and Miyake S: Thoracoscopic esophagectomy using prone positioning. Ann Thoracic Cardiovasc Surg 19: 399-408, 2013.

20 Osugi H, Takemura M, Higashino M, Takada N, Lee S and Kinoshita H: A comparison of video-assisted thoracoscopic oesophagectomy and radical lymph node dissection for squamous cell cancer of the oesophagus with open operation. $\mathrm{Br}$ J Surg 90: 108-113, 2003.

21 Heikkila K, Ebrahim S and Lawlor DA: A systematic review of the association between circulating concentrations of $\mathrm{C}$ reactive protein and cancer. J Epidemiol Community Health 61: 824-833, 2007. 